\title{
Disturbed ammonium assimilation is associated with growth inhibition of roots in rice seedlings caused by $\mathrm{NaCl}$
}

\author{
Chuan Chi Lin \& Ching Huei Kao* \\ Department of Agronomy, National Taiwan University, Taipei, Taiwan, Republic of China $\left(^{*}\right.$ Author for \\ correspondence)
}

Received 19 May 1995; accepted 20 July 1995

Key words: ammonium assimilation, $\mathrm{NaCl}$ stress, Oryza sativa $\mathrm{L}$, root growth

\begin{abstract}
The effects of $\mathrm{NaCl}$ on changes in ammonium level and enzyme activities of ammonium assimilation in roots growth of rice (Oryza sativa L.) seedlings were investigated. $\mathrm{NaCl}$ was effective in inhibiting root growth and stimulated the accumulation of ammonium in roots. Accumulation of ammonium in roots preceded inhibition of root growth caused by $\mathrm{NaCl}$. Both effects caused by $\mathrm{NaCl}$ are reversible. Exogenous ammonium chloride and methionine sulfoximine (MSO), which caused ammonium accumulation in roots, inhibited root growth of rice seedlings. $\mathrm{NaCl}$ decreased glutamine synthetase and glutamate synthase activities in roots, but increased glutamate dehydrogenase activity. The growth inhibition of roots by $\mathrm{NaCl}$ or MSO could be reversed by the addition of L-glutamic acid or L-glutamine. The current results suggest that disturbance of ammonium assimilation in roots may be involved in regulating root growth reduction caused by $\mathrm{NaCl}$.
\end{abstract}

Abbreviations: $\mathrm{GDH}=$ glutamate dehydrogenase; GOGAT = glutamate synthase; GS = glutamine synthetase; $\mathrm{MSO}=$ methionine sulfoximine

\section{Introduction}

Early work by Joshi et al. [3] underlies the hypothesis that ammonium assimilation and amino acid metabolism are integrally involved in plant responses to salinity. Enzyme activities of ammonium assimilation in plants have been shown to be affected by $\mathrm{NaCl}[8,12]$. Ammonium accumulation in leaves of some subtropical grasses has been demonstrated under salinity stress [10]. However, this is the only report on ammonium accumulation in plants exposed to salt stress. It is known that ammonium strongly inhibits the growth of many plants $[1,5]$. However, it is not known whether growth inhibition of plants in response to salinity is closely related to ammonium accumulation. In the present investigation, we studied the effects of $\mathrm{NaCl}$ on changes in ammonium level and activities of enzymes involved in ammonium assimilation in roots and root growth of rice seedlings.

\section{Materials and methods}

Rice (Oryza sativa L., cv. Taichung Native 1) seeds were sterilized with $2.5 \%$ sodium hypochlorite for 15 min and washed extensively with distilled water. These seeds were then germinated in a Petri dish $(20 \mathrm{~cm})$ containing distilled water at $37^{\circ} \mathrm{C}$ under dark conditions. After 1-day incubation, uniformly germinated seeds were selected and transferred to a Petri dish $(9.0 \mathrm{~cm})$ containing two sheets of Whatman No. 1 filter paper moistened with $10 \mathrm{~mL}$ of distilled water or test solution. Each Petri dish contained 20 germinated seeds. Each treatment was replicated 4 times. The germinated seeds were allowed to growth at $27^{\circ} \mathrm{C}$ in darkness. To avoid the lose by evaporation and taken up by the seeds, a further $3 \mathrm{~mL}$ of distilled water or test solutions was added to each Petri dish on day 3 of the growth.

Ammonium was measured in the crude extract by the Berthelot reaction, modified according to Weatherburn [13]. For ammonium determination in 
roots of rice seedlings, 10 roots were homogenized with a mortar and pestle using $3 \mathrm{~mL} 0.3 \mathrm{~m} M$ sulphuric acid ( $\mathrm{pH} 3.5$ ). The homogenate was centrifuged for $10 \mathrm{~min}$ at $39000 \mathrm{~g}$. Two-hundred $\mu \mathrm{L}$ of clear supernatant were diluted by $0.3 \mathrm{~m} M$ sulphuric acid to a final volume of $4 \mathrm{~mL}$. For the colour reaction, $0.5 \mathrm{~mL}$ of solution A ( $5 \mathrm{~g}$ phenol, $25 \mathrm{mg}$ nitroprusside dissolved in $100 \mathrm{~mL}$ water) and then $0.5 \mathrm{~mL}$ of solution $\mathrm{B}(40 \mathrm{~mL}$ $5 \%$ sodium hypochlorite and $2.5 \mathrm{~g} \mathrm{NaOH}$ were mixed, and then made up to a final volume of $100 \mathrm{~mL}$ with distilled water) were added. Incubation was carried out with gentle shaking in a water bath at $37^{\circ} \mathrm{C}$ for $20 \mathrm{~min}$. The absorbance was measured at $625 \mathrm{~nm}$ against the control without extract. Ammonium levels were calculated using an extinction coefficicnt of $3.9982 \mu \mathrm{mol}^{-1}$ $\mathrm{cm}^{-1}$ and expressed as $\mu \mathrm{mol} \mathrm{g}^{-1}$ fresh weight.

For extraction of enzymes, plant tissue was homogenized with $10 \mathrm{~m} M$ Tris- $\mathrm{HCl}$ buffer ( $\mathrm{pH} 7.6$, containing $1 \mathrm{~m} M \mathrm{MgCl}_{2}, 1 \mathrm{~m} M$ EDTA and $1 \mathrm{~m} M$ 2-mercaptoethanol in a chilled pestle and mortar. The homogenate was centrifuged at $15000 \mathrm{~g}$ for $30 \mathrm{~min}$ and the resulting supernatant was used for determination of enzyme activities. The whole extraction procedure was carried out at $4{ }^{\circ} \mathrm{C}$.

GS (EC 6.3.1.2) was assayed by the method of Oaks et al. [9]. The reaction mixture contained in a final volume of $1 \mathrm{~mL}, 80 \mu \mathrm{mol}$ Tris- $\mathrm{HCl}$ buffer, 40 $\mu$ mol L-glutamic acid, $8 \mu \mathrm{mol} \mathrm{ATP,} 24 \mu \mathrm{mol} \mathrm{MgSO}_{4}$, and $16 \mu \mathrm{mol} \mathrm{NH} \mathrm{N}_{2} \mathrm{OH}$; the final $\mathrm{pH}$ was 8.0. Reaction was started by addition of the enzyme extract and after incubation for $30 \mathrm{~min}$ at $30^{\circ} \mathrm{C}$ was stopped by adding $2 \mathrm{~mL} \mathrm{2.5 \% (w/v)} \mathrm{FeCl}_{3}$ and 5\% (w/v) trichloroacetic acid in $1.5 \mathrm{M} \mathrm{HCl}$. After centrifugation at $3000 \mathrm{~g}$ the absorbance of the supernatant was read at $540 \mathrm{~nm}$. One unit of GS activity is defined as $1 \mu \mathrm{mol} \mathrm{L}$-glutamate $\gamma$-monohydroxamate formed per min.

GOGAT (EC 1.4.7.1) activity was determined after the method of Singh \& Srivastava [11]. The assay mixture contained $0.4 \mathrm{~mL} 20 \mathrm{~m} M$ L-glutamine, $0.05 \mathrm{~mL}$ $0.1 M$ 2-oxoglutarate, $0.1 \mathrm{~mL} 10 \mathrm{mM} \mathrm{KCl}, 0.2 \mathrm{~mL}$ $3 \mathrm{~m} M \mathrm{NADH}$ and $0.5 \mathrm{~mL}$ of the enzyme extract in a final volume of $3 \mathrm{~mL}$, made up with $25 \mathrm{mM}$ Tris- $\mathrm{HCl}$ buffer ( $\mathrm{pH} 7.6$ ). The reaction was startcd by adding Lglutamine immediately following the enzyme preparation. The decrease in absorbance was recorded for 3 $\min$ at $340 \mathrm{~nm}$. One unit of enzyme activity is defined as a decrease of $1 \mathrm{OD}_{340}$ per min.

GDH (ED 1.4.1.2) activity was assayed by the method of Kanamori et al. [4]. The assay mixture contained $0.3 \mathrm{~mL} 0.1 M$ 2-oxoglutarate, $0.3 \mathrm{~mL} 1 M$ $\mathrm{NH}_{4} \mathrm{Cl}, 0.2 \mathrm{~mL} 3 \mathrm{~m} M \mathrm{NADH}$ and $1 \mathrm{~mL}$ of the enzyme

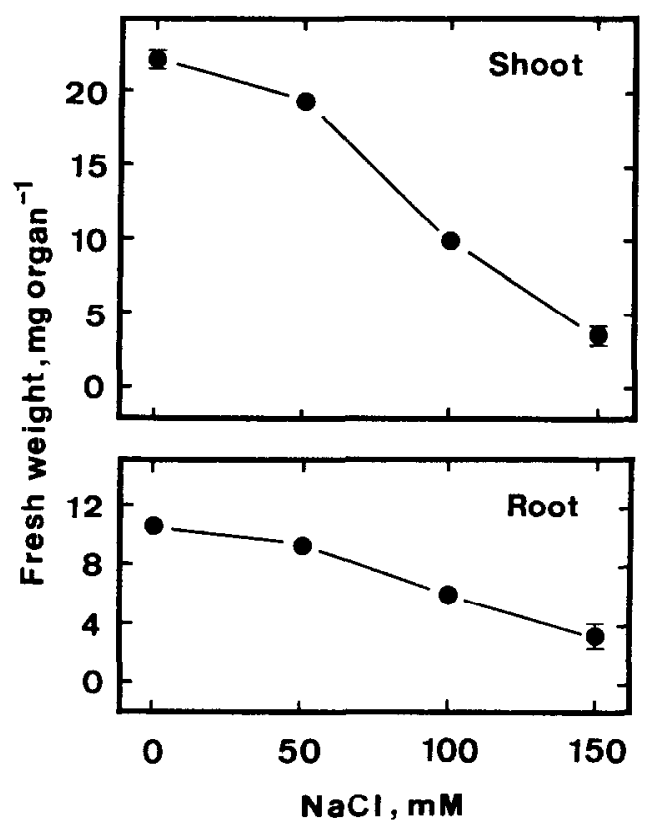

Fig. 1. Effects of $\mathrm{NaCl}$ on seedling growth of rice. Seedling growth was measured after 5 days of treatment. Vertical bars represent standard errors. Only those standard errors larger than the symbols are shown.

extract in a final volume of $3 \mathrm{~mL}$, made up with 0.2 $M$ Tris- $\mathrm{HCl}$ buffer ( $\mathrm{pH} 8.0$ ). Reaction was started by adding the enzyme extract. The decrease in absorbance was recorded for $3 \mathrm{~min}$ at $340 \mathrm{~nm}$. One unit of enzyme activity is defined as a decrease of $1 \mathrm{OD}_{340}$ per min.

For all measurements, each treatment was repeated four times. All experiments described here were repeated three times. Similar results and identical trends were obtained each time. The data reported here arc from a single experiment.

\section{Results}

The growth of rice seedlings was followed by measuring the fresh weight of shoots or roots. Increasing concentrations of $\mathrm{NaCl}$ from 50 to $150 \mathrm{mM}$ progressively decreased shoot and root growth (Fig. 1). The growth of shoots and roots at $150 \mathrm{mM} \mathrm{NaCl}$ was reduced to 15 and $30 \%$, respectively, of the control value.

GS and GOGAT activities in roots were found to decrease in a concentration-dependent manner with $\mathrm{NaCl}$ treatment (Fig. 2). In contrast to GS and GOGAT, the GDH activity in roots increased in the presence of $\mathrm{NaCl}$ (Fig. 2). In shoots of rice seedlings, $\mathrm{NaCl}$ slightly 

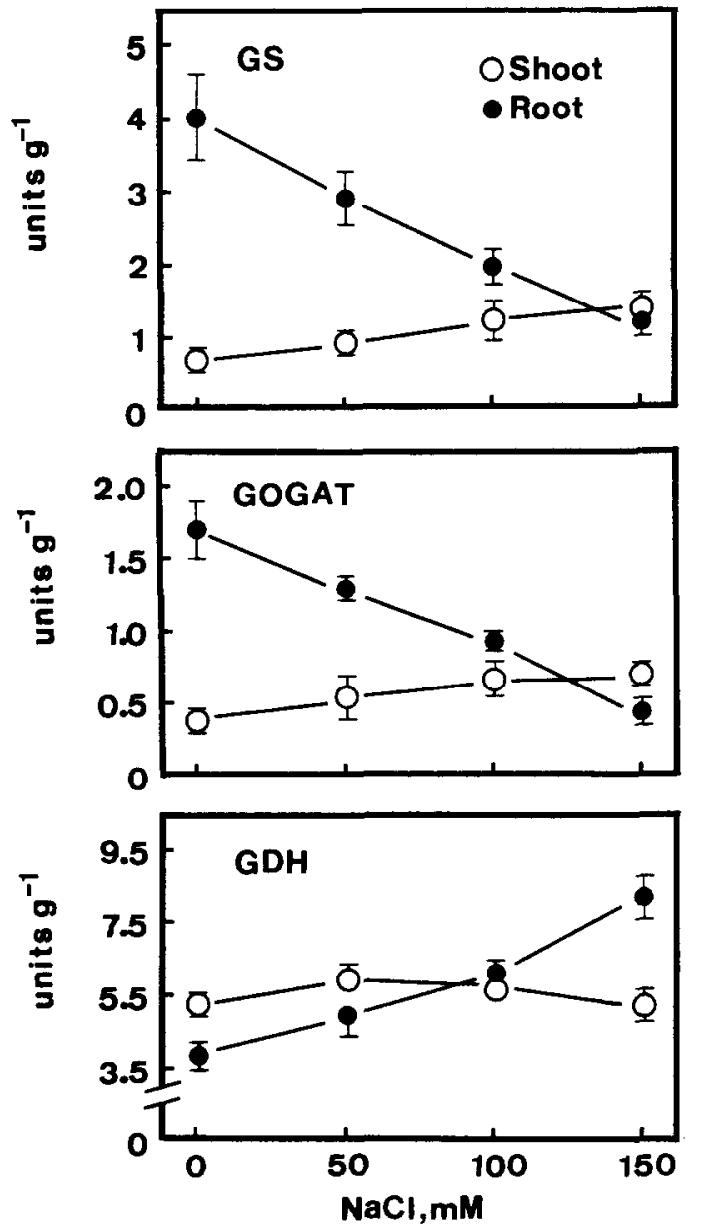

Fig. 2. Effects of $\mathrm{NaCl}$ on GS, GOGAT and GDH activities in shoots and roots of rice seedlings. Enzyme activities were determined after 5 days of treatments. Vertical bars represent standard errors. Only those standard errors larger than the symbols are shown.

increased GS and GOGAT activities but did not affect GDH activities (Fig. 2). It seems that GS and GOGAT in shoots are enzymes resistant to $\mathrm{NaCl}$ stress.

The effects of $\mathrm{NaCl}$ on ammonium levels in shoots and roots of rice seedlings are presented in Fig. 3. Increasing concentration of $\mathrm{NaCl}$ from 50 to 150 $\mathrm{m} M$ progressively increased the ammonium level in roots. However, ammonium accumulation in shoots was observed only when seedlings were treated at high concentration $(100-150 \mathrm{mM})$ of $\mathrm{NaCl}$. It seems that root growth reduction caused by $\mathrm{NaCl}$ is closely linked with ammonium accumulation in roots.

If ammonium accumulation is important in regulating growth reduction of roots but not shoots caused by $\mathrm{NaCl}$, then exogenous application of ammonium chlo-

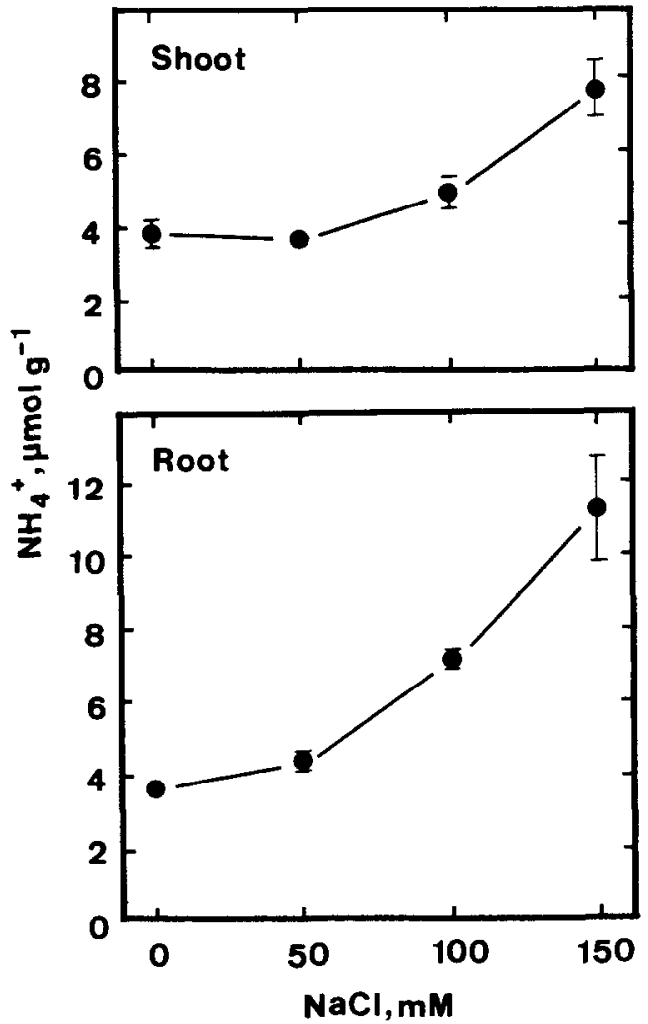

Fig. 3. Effects of $\mathrm{NaCl}$ on ammonium levels in shoots and roots of rice seedlings. Ammonium level was determined after 5 days of treatments. Vertical bars represent standard errors. Only those standard errors larger than the symbols are shown.

ride would be expected to reduce root growth but not shoot growth. As indicated in Fig. 4, ammonium chloride significantly inhibited root growth and increased the ammonium level in roots. However, addition of ammonium chloride up to $10 \mathrm{~m} M$ did not inhibit shoot growth (data not shown).

Miflin \& Lea [7] suggested that an active GS could be responsible for the efficient assimilation of ammonium, and there is evidence that addition of MSO, an inhibitor of GS, results in an accumulation of ammonium [6, 7]. To characterize further the role of ammonium accumulation in regulating root growth reduction under $\mathrm{NaCl}$ stress, rice seedlings were grown in the presence of various concentrations of MSO. As indicated in Fig. 5, MSO increased ammonium level in roots and decreased root growth. From the shape of the curves, it is apparent that ammonium level is closely associated with root growth reduction. It was also found that MSO did not inhibit shoot growth of rice seedlings (data not shown). 


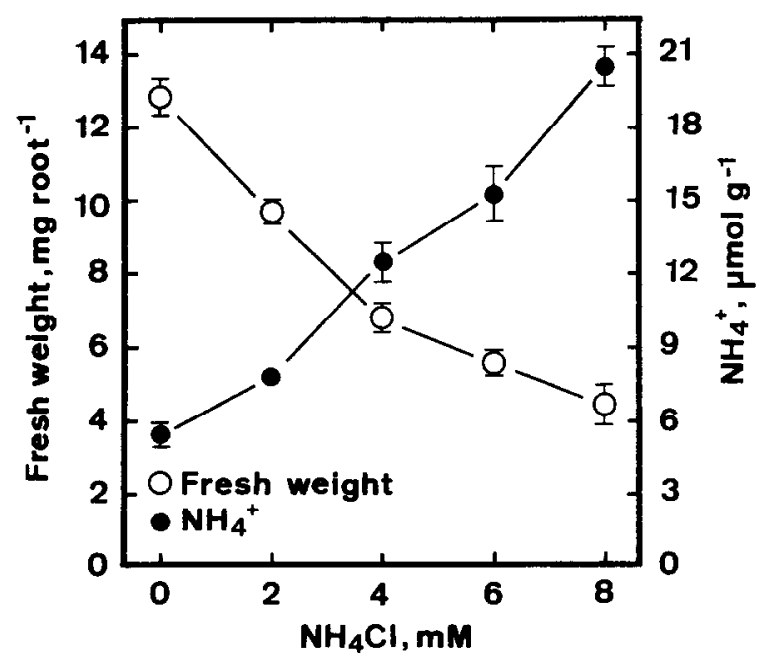

Fig. 4. Effects of ammonium chloride on root growth and ammonium level in roots of rice seedlings. Root growth and ammonium level were measured after 5 days of treatment. Vertical bars represent standard errors. Only those standard errors larger than the symbols are shown.

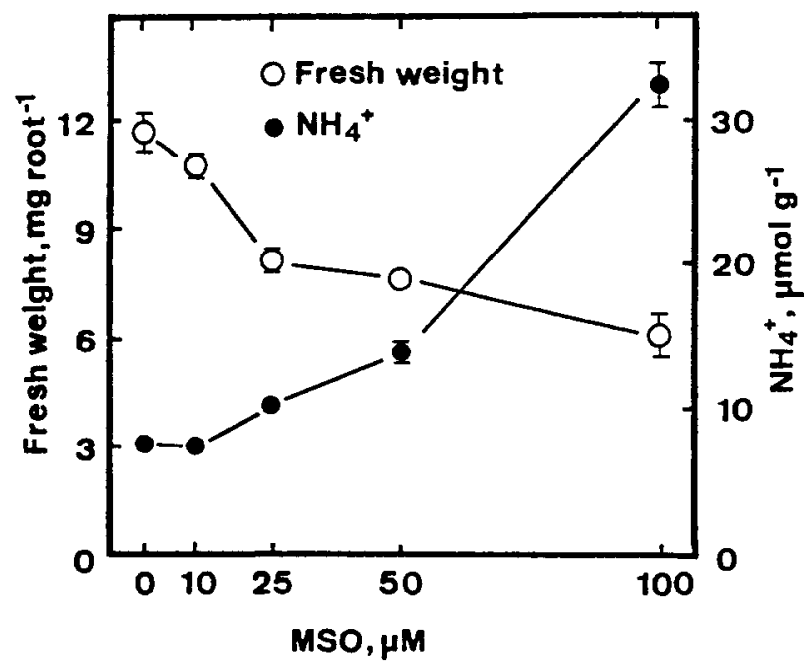

Fig. 5. Effects of methionine sulfoximine (MSO) on root growth and ammonium level in roots of rice seedlings. Root growth and ammonium level were determined after 5 days of treatment. Vertical bars represent standard errors. Only those standard errors larger than the symbols are shown.

If rice seedlings maintained for 2 days on $\mathrm{NaCl}$ $(150 \mathrm{mM})$ are transferred to distilled water, they then resume root growth (Fig. 6). However, only slight growth was observed if seedlings remained in $\mathrm{NaCl}$ (Fig. 6). Figure 6 also shows that the ammonium level in roots of seedlings remaining in the $\mathrm{NaCl}$ medium

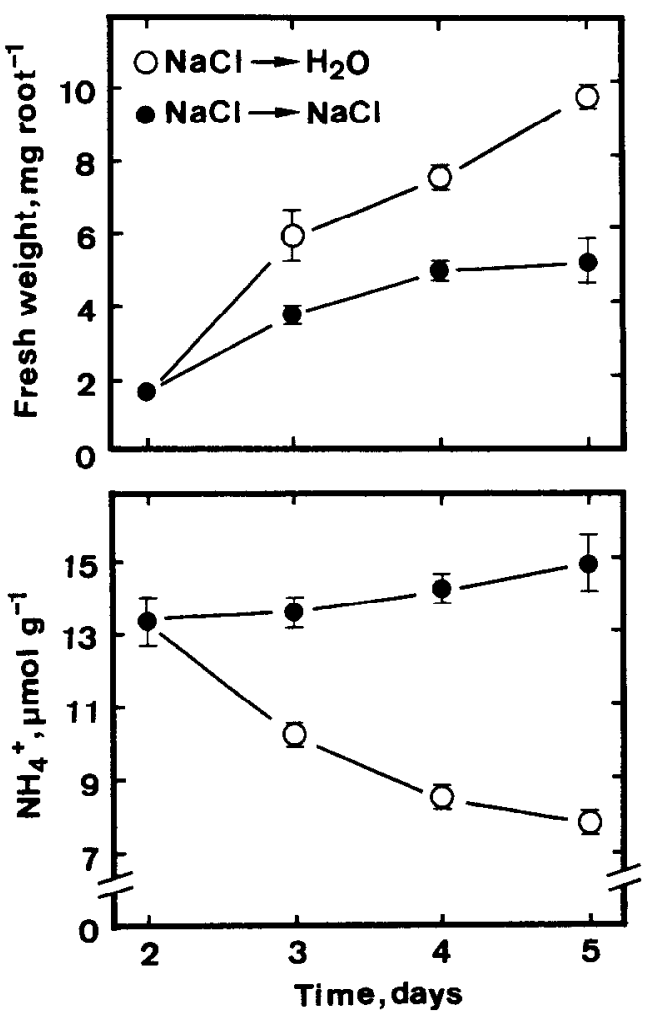

Fig. 6. Changes in fresh weight of and ammonium level in roots of $\mathrm{NaCl}$-treated rice seedlings grown in the presence or absence of $\mathrm{NaCl}(150 \mathrm{mM})$. Rice seeds were germinated for 2 days in $\mathrm{NaCl}$ $(150 \mathrm{mM})$ and then seedlings were transferred to distilled water $(O)$ and $\mathrm{NaCl}(\Theta)$, respectively. Vertical bars represent standard errors.

was higher than that of seedlings transferred to distilled water.

To test the causal relationship between ammonium accumulation and root growth reduction caused by $\mathrm{NaCl}, 2$-day-old seedlings were transferred to distilled water and $\mathrm{NaCl}$, respectively, for a short time. Changes in ammonium levels in roots and root growth were then monitored. As shown in Fig. 7, ammonium accumulation was observed at $4 \mathrm{~h}$ after treatment, whereas a reduction in root growth was visible $8 \mathrm{~h}$ after treatment started.

Table 1 shows the effect of L-glutamic acid and Lglutamine on $\mathrm{NaCl}$ - and $\mathrm{MSO}$-inhibited root growth. Addition of L-glutamine or L-glutamic acid alone resulted in a slight reduction of root growth when compared with the controls. However, addition of Lglutamic acid or L-glutamine to the medium with $\mathrm{NaCl}$, caused partial recovery of root growth when compared with root growth of rice seedlings treated only with $\mathrm{NaCl}$ alone. Table 1 also shows that MSO-inhibited 

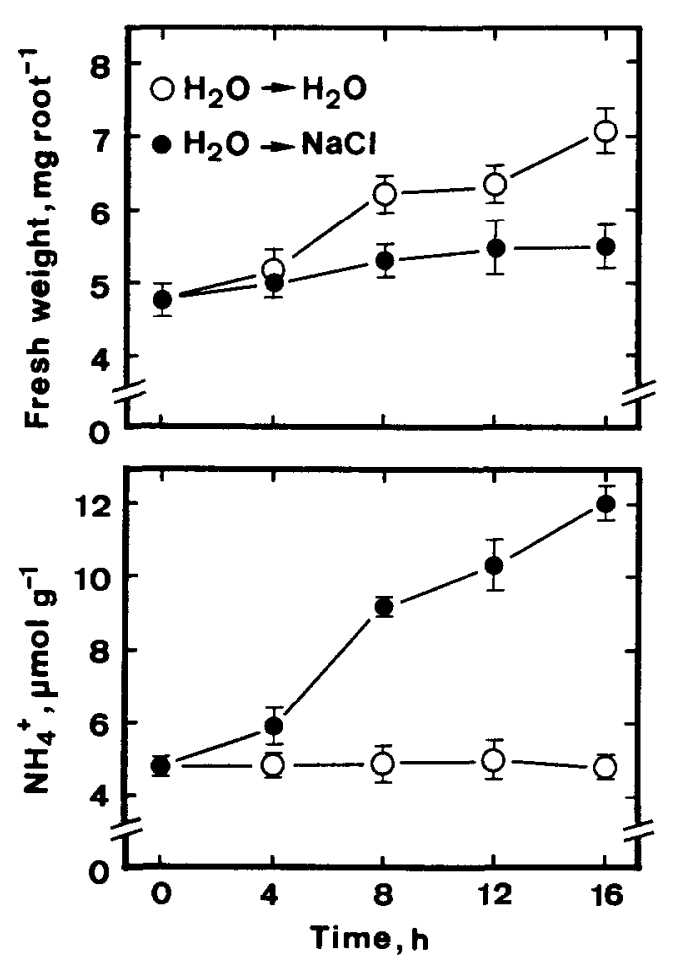

Fig. 7. Changes in fresh weight of and ammonium level in roots of 2-day-old-rice seedlings grown in the presence or absence of $\mathrm{NaCl}$ $(150 \mathrm{mM})$. Rice seeds were germinated for 2 days in distilled water and then seedlings were transferred to $\mathrm{NaCl}(\boldsymbol{C})$ or remained in distilled water $(O)$. Vertical bars represent standard errors.

Table 1. Effect of L-glutamic acid and L-glutamine on $\mathrm{NaCl}$ and methionine sulfoximine (MSO)- inhibited root growth of rice seedlings. The concentrations for $\mathrm{NaCl}, \mathrm{MSO}, \mathrm{L}$-glutamic acid and L-glutamine were $150 \mathrm{mM}, 50 \mu M, 1 \mathrm{mM}$ and $1 \mathrm{mM}$, respectively. Root growth was determined after 5 days of treatment. Values are means with standard errors

\begin{tabular}{lc}
\hline Treatment & Fresh weight $\left(\mathrm{mg} \mathrm{root}^{-1}\right)$ \\
\hline Control & $12.0 \pm 0.3$ \\
$\mathrm{NaCl}$ & $4.3 \pm 0.3$ \\
$\mathrm{MSO}$ & $6.7 \pm 0.1$ \\
L-Glutamic acid & $10.4 \pm 0.4$ \\
L-Glutamine & $10.2 \pm 0.6$ \\
$\mathrm{NaCl}+$ L-Glutamic acid & $5.5 \pm 0.2$ \\
$\mathrm{NaCl}+$ L-Glutamine & $6.0 \pm 0.3$ \\
$\mathrm{MSO}+$ L-Glutamic acid & $8.5 \pm 0.2$ \\
$\mathrm{MSO}+$ L-Glutamine & $8.2 \pm 0.2$ \\
\hline
\end{tabular}

root growth could be partially reversed by the addition of L-glutamine or L-glutamic acid.

\section{Discussion}

In the present study, we show that ammonium accumulates in both shoots and roots of seedlings exposed to $\mathrm{NaCl}$. However, ammonium accumulation in shoots was observed only at high concentrations of $\mathrm{NaCl}$. Ammonium ion is a central intermediate in the metabolism of nitrogen in plants. Ammonium is produced during nitrate assimilation, deamination of amino acids from storage proteins and photorespiration [6]. The assimilation of ammonium requires carbon skeletons, energy, GS and GOGAT. Since our experiments were conducted in darkness, ammonium is unlikely to have been produced from photorespiration. In the present investigation, we have observed that $\mathrm{NaCl}$ treatment results in inhibition of GS and GOGAT activities in roots. This inhibition may result, at least in part, in the accumulation of ammonium accumulation in roots of rice seedlings in response to $\mathrm{NaCl}$.

Our results indicate that ammonium accumulation is likely to participate in the regulation of root growth reduction of rice seedlings under $\mathrm{NaCl}$ condition. This conclusion is based on the observations that (a) ammonium accumulation in roots preceded root growth reduction caused by $\mathrm{NaCl}$; (b) ammonium levels in roots were inversely associated with root growth; (c) rice seedlings fed with ammonium chloride or MSO, which resulted in an accumulation of ammonium in roots, reduced root growth in the same way that $\mathrm{NaCl}$ did; and (d) when rice seedlings pretreated with $\mathrm{NaCl}$ were transferred to distilled water, root growth was restored and ammonium levels in the roots declined.

High levels of ammonium are known to have toxic effects in plant cells [5]. To inhibit root growth, ammonium must be blocking cell division or expansion. Perhaps, ammonium accumulation in root cells is sufficient to disturb metabolic pathways, or ion and $\mathrm{pH}$ balances $[2,5]$. Whatever the mechanism, the inhibition is reversible, because root growth could be restored in $\mathrm{NaCl}$-treated seedlings if they were transferred to distilled water.

Plant growth is generally considered to be an energy-requiring process. Thus, an elevated ammonium levels in root cells caused by $\mathrm{NaCl}$ are most likely acting as a way to save energy by inhibiting root growth and as a readily utilizable source of nitrogen once $\mathrm{NaCl}$ stress is relieved.

Inhibition of GS and GOGAT activities in roots by $\mathrm{NaCl}$ and the effect of MSO on roots may also result in lowering the levels of L-glutamine and L- 
glutamic acid. Since addition of L-glutamine or Lglutamic acid causes partial recovery of root growth inhibition caused by $\mathrm{NaCl}$ or $\mathrm{MSO}$, it seems that the lack of L-glutamine and L-glutamic acid is probably another reason for the growth inhibition of rice roots under $\mathrm{NaCl}$ stress or treated with MSO. In conclusion, disturbance of ammonium assimilation in roots by $\mathrm{NaCl}$, which results in an increase of ammonium and a decrease of L-glutamine and/or L-glutamic acid, seems to be associated with growth reduction of roots.

\section{Acknowledgements}

This work was supported by a grant from the National Science Council of the Republic of China (NSC 842321-B002-097).

\section{References}

1. Cao Y, Glass ADM and Crawford NM (1993) Ammonium inhibition of Arabidopsis root growth can be reversed by potassium and by auxin resistance mutation aux $1, a x r l$, and axr2. Plant Physiol 102: 983-989

2. Haynes RJ (1986) Uptake and assimilation of mineral nitrogen by plants. In: Haynes RJ (eds) Mineral Nitrogen in the PlantSoil System, pp 303-378. San Diego: Academic Press
3. Joshi G, Dolan T, Gee R and Saltman P (1962) Sodium chloride effect on dark fixation of $\mathrm{CO}_{2}$ by marine and terrestrial plants. Plant Physiol 37: 446-449

4. Kanamori T, Konishi S and Takahashi E (1972) Inducible formation of glutamate dehydrogenase in rice plant roots by the addition of ammonia to the media. Physiol Plant 26: 1-6

5. Marschner H (1986) Mineral Nutrition of Higher Plants. San Diego: Academic Press

6. Miflin BJ and Lea PJ (1976) The pathway of nitrogen assimilation in plants. Phytochemistry 15: 873-885

7. Miflin BJ and Lea PJ (1977) Amino acid metabolism. Annu Rev Plant Physiol 28: 199-329

8. Misra N and Dwivedi UN (1990) Nitrogen assirnilation in germinating Phaseolus aurens seeds under saline stress. J Plant Physiol 135: 719-724

9. Oaks A, Stulen J, Jones K, Winspear MJ and Boosel IL (1980) Enzymes of nitrogen assimilation in maize roots. Planta 148 : 477-484

10. Pulich WM (1986) Variation in leaf soluble amino acids and ammonium content in subtropical seagrasses related to salinity. Plant Physiol 80: 283-286

11. Singh RD and Srivastava HS (1986) Increase in glutamate synthase (NADH) activity in maize seedlings in response to nitrate and ammonium nitrogen. Physiol Plant 66: 413-416

12. Stewart GR and Rhodes D (1978) Nitrogen metabolism of halophytes III. Enzymes of ammonia assimilation. New Phytol 80: 307-316

13. Weatherburn MW (1967) Phenol-hypochlorite reaction for determination of ammonia. Anal Chem 39: 971-974 